\title{
Increased Intercultural Sensitivity Through Culture
}

\author{
Meutia Nauly', Ridhoi Meilona Purba' ${ }^{2}$ Fasti Rola ${ }^{3}$
}

\author{
Departement of Social Psychology12 \\ Departement of Educational Psychology 3 \\ Fakultas Psikologi USU, Medan, Indonesia \\ tianauly@gmail.com ${ }^{1}$
}

\begin{abstract}
This research is a mixed design with the sequential method. In accordance with the purpose to the study, the results showed that the intercultural sensitivity (consisting of dimensions: Group Harmony, Multiculturality, Active Sensitivity, Initial Cautiousness, Conflict Avoidance, Implicit Communication, Deliberation and Consensus) is influence by the values of Batak, Flexibility Thinking, and Openness. These results were obtained through a quantitative study involving four instruments were analyzed by multiple regression of the 343 university students of Batak in Medan. After the first study, we were doing a qualitative study through Focus Group Discussion to seven groups (36 students), representatives from four division of Batak: Toba, Karo, Simalungun and Mandailing. Themes are found to be associated with: the abilitiy to adapt without losing their identity; dare to act and express opinions; not ashamed of being a Batak; and present themselves as Good Batak. We found several differences between the four sub-tribe of Batak. It discussed the implications to utilize these results to create a training module that will increase intercultural sensitivity for the student wider.
\end{abstract}

Keywords: Local Wisdom, Culture, and Law

\section{INTRODUCTION}

Indonesia is a country that has a diversity of different sides. In addition to the diverse cultures and languages, there is also a mix of religion, ethnicity, and customs that have diverged since time immemorial (Hadiluwih, 2008). Arifinsyah (in Anto, 2012) as well mentioned that in Indonesia Today, there are no less than 100 tribes with 726 tribal language diversity.

Medan City is considered to manage the differences, because pluralism eight cultures and ethnic Chinese and Indian/Tamil), even though potential for conflict is high (Pelly, 2016). The ability to be competent to resolve conflicts this diversity is not necessarily derived from the condition of the existing diversity, but it takes understanding ourselves. Individual's perspective self-awareness necessary to develop awareness of diversity.

Someone understands about the cultural values that he had was a very important thing, before he can begin to develop sensitivity to other cultures. Because by recognizing the values that he carries, one can be aware of biases that cause misunderstandings he experienced while interacting with people from other's (Pedersen, 1994;
Panggabean, 2010). The discovery of the power contained).

Within its own cultural values goes through a process called by Khayyam (1989) as a transformation. Basically, that is a process in which the ideal type of society that had been created by their particular values that have been held by the community itself. In the case of this study, the transformation of the culture in question is the establishment of intercultural sensitivity. It is as a way to manage cultural discrepancies in students in Medan derived from values of their own homelands. When these differences have successfully managed well, undoubtedly expected ideal type of society that is a pluralistic society (Suparlan, 1999) will be formed.

In general, Panggabean (2004) defines intercultural sensitivity as the ability to adapt flexibly in ambiguous situations caused by cultural differences. Intercultural sensitivity consists of dimensions: Group Harmony, Multiculturality, Active sensitivity, Initial cautiousness, Conflict avoidance, Implicit communication, Deliberation and consensus. Openness is individuals who have an appreciation for ideas and unusual art. Flexibility is a positive attitude towards change. Someone associates with 
intercultural sensitivity in terms of willingness to renew its behavior based on respect on behalf of different cultures (Bhawuk and Brislin, 1992).

Batak tribe is one of the tribes in Indonesia, which is considered a strong hold customary. Cultural values known as $3 \mathrm{H}$ namely hagabeon (welfare), hasangapon (honor) and hamoraon (wealth) (Nauly and Fransisca, 2015; Baiduri, 2015). Quite a lot of people Batak Toba who wanders away to other cities in Indonesia in order to meet the demands of all three Hs, also with the aim further expand and strengthen the tribe (Nauly, 2003; Pelly, 2016).

A person who is faced with a culture that has a different value to him would experience a kind of alienation, which is called by Panggabean (2010) and Pedersen (1994) as strangeness. Alienation is overcome by the individual through the familiarity process that requires openness and flexibility of thinking (Panggabean, 2010). The process of alienation towards this familiarity requires a cultural learning process that leads to intercultural competences. One of them is sensitivity between culture based upon the research is considered able to predict the success of cooperation between cultures (Cui and Van Den Berg, 1991).

So far, there have been several studies that support the role of intercultural sensitivity adjustment in the Indonesian people in other countries. Rikkidaniel (2006) showed a significant positive correlation between the level this variable to the value of GPA students studying in Australia. Kurniawan descriptive study (2006) illustrates how the use of intercultural sensitivity of Indonesian students studying in the United States to solve the problems associated with cultural differences.

Based on the above explanation, the hypothesis of this study is: Cultural values' Batak Toba, Thinking Flexibility and Openness play a significant role in the formation of intercultural sensitivity in students. Questions for Qualitative Research: How can someone to be taught batak values in the family on the diversity of situations in the city of Medan?

\section{METHOD}

\section{A. Participant and Instrument}

The study design is a mixed research design, sequential model (Cresswell, 2014), first performed a quantitative correlation, using four measuring equipment for each variable. Intercultural sensitivity of the outcome variable and the predictor variables consisted of cultural values of batak, flexibility of thinking and openness. Participants are students of University of North Sumatra, university students and students of state universities Nomensen terrain with data retrieval in nonprobability sampling, named accidental sampling number of 343 students batak ethnicity. Results of analysis of the measuring instrument, found Cronbach alpha values for the measuring instrument 0.779 intercultural sensitivity. The reliability of the measuring instrument values of Batak (Cronbach alpha) 0.759. The scale had a reliability 0.863 openness and flexibility of measuring instruments in the form on a scale of 0.673 .

\section{B. Research Design}

This study performed a descriptive qualitative study took the data by focus group discussion to students from four sub batak tribes, namely the Toba, Karo, Simalungun and Mandailing. Participants at this stage that the students are participant's batak ethnicity, have knowledge within the culture that he embraced, at least be able to speak their respective regions. FGD was conducted to explore the values of these subtribe consists of eight groups $(n=34$ students), the Toba (second group consisted of 10 participants, Karo (consisting of two groups of nine people, Mandailing (consisting of two groups numbered 9 and Simalungun (consisting of one groups of six people) that contribute toward the improvement of intercultural sensitivity. The discussions led by questioning the 7 th dimension of intercultural sensitivity in terms of linkages with the values / wisdom / motto / rhymes in the family as well as the efforts made to settle them. Each group has a note taker who will transcribe the discussion process and the results of each participant, in addition to using a tape recorder.

\section{RESULT}

It results from Study 1: Based on the results from the field, the data were analyzed using multiple regressions. Outcome variables are Sensitivity Between Cultures and three predictor variables the values of Batak, openness and flexibility of thinking. Analysis by descriptive can be seen, the average value of intercultural sensitivity from 346 participants was 3.570; the Batak cultural value is 3.380; the mean value of Cognitive Flexibility was 
3.517; Openness in of participants was 3.455; as shown in table 1 below.

Table I: Descriptive Statistics

\begin{tabular}{|l|l|l|l|}
\hline & Mean & $\begin{array}{l}\text { Std } \\
\text { Deviatio } \\
\text { n }\end{array}$ & N \\
\hline $\begin{array}{l}\text { Sensitivitas } \\
\text { antarbuday } \\
\text { a }\end{array}$ & 3,5705 &, 33927 & 346 \\
\hline $\begin{array}{l}\text { Nilai } \\
\text { budaya } \\
\text { Batak }\end{array}$ & 3,3804 &, 33092 & 346 \\
\hline $\begin{array}{l}\text { Fleksibilita } \\
\text { s Kognitif }\end{array}$ & 3,5167 &, 41344 & 346 \\
\hline Openness & 3,4554 &, 39828 & 346 \\
\hline
\end{tabular}

Based on the above results, it can be concluded the mean participant has a value that is above the average theoretical value (score 3 ) on intercultural sensitivity variables, the values of Batak, flexibility of thinking and Openness.

Based on the results of a quantitative study found that the values of the Batak culture, flexibility of thought and openness contribute significantly to intercultural sensitivity. These results are consistent with the hypothesis that was built.

Based on the analysis to participants, with Dependent Variable intercultural sensitivity and three independent variables were the values of Batak, openness and cognitive flexibility. The results showed the model fit, with a 0.05 significance level. It means that the first hypothesis is accepted, the value of $\mathrm{R}=0505$; $\mathrm{R}$ squared $0-255$ with $\mathrm{p} 0.0001 ; \mathrm{F}$ $(\mathrm{df} 1=3 ; \mathrm{df} 2=342)=39.54$ (Table 2).

This study was also conducted a further analysis to determine that any of the independent variables that significantly affect the dependent variables. The three variables affect meaningfully. The cultural values of Batak $(\mathrm{t}=5.2977 ; \mathrm{df} 1=3$; df2 $=342, \mathrm{p}=0.0001)$, cognitive flexibility $(\mathrm{t}=4.603 ; \mathrm{df} 1$ $=3 ; \mathrm{df} 2=342, \mathrm{p}=0.0001)$ and openness $(\mathrm{t}=3.340$; df $1=3 ;$ df $2=342, p=0.001$ ) substantially affect the level of intercultural sensitivity.

A significant relationship between the values of Batak Toba and intercultural sensitivity had previously been found by Partogi in their studies regarding the Batak migrants in Jakarta (Partogi, 2011). Batak people known by his hard work to meet the demands of Hamoraon, Hagabeon and Hasangapon. Hard work is also displayed in the association together with other ethnic in diversity. The hard work is termed by Pelly (2016) as an inner scream credos or batak people to become number one, which lets it meet the demands of its cultural mission is toward the three $\mathrm{H}$.

Study 2: the results of qualitative research: The themes were obtained related to the ability to adapt without losing their identity, dare to act and express their opinions, not ashamed of being a Batak present yourself as a good person. Besides the positive aspects that encouragement the dimensions of intercultural sensitivity, also found some things that do not support it. Among others of Batak Simalungun tendency to dissolve in the culture of others without taking care of their own culture, as well as the conclusions Simalungun group:

"Kondisi pertemuan dengan budaya-budaya lainnya membuat mereka cenderung mengadopsi budaya lain tersebut, ini cukup menjadi perhatian yang cukup serius dalam diskusi di kelompok partisipan" (FGD 1 Simalungun).

\section{Multiculturality and Implicit Communication:}

Multiculturality:

"Marbisuk pintar-pintar", They are expected to be in this life can read the situation, and circumstances are not tricked wherever life. (FGD 2 Karo)

\section{Implicit Communication:}

Disirik madung mangarti: According to them should be sensitive and people immediately understand what the purpose of the gaze of others when in a given situation When other people are in the area revealed parents, unang baen songoni, nadong songoni dialaian, pantang. One could keep the family name and still behave according to the area attended (FGD 2 Mandailing). Marbisuk: (wise) reading of the situation, avoid if anyone does not like us (Simalungun).

For Group Batak Toba: FGD results to show the Toba Batak culture has many values that support intercultural sensitivity, among others: Marbisuk pintar-pintar, meaning to this life can read the situation, and circumstances are not tricked wherever life. This statement supports multiculturalism, which means their willingness to embrace differences.

Sata bi hata, is the expectation that the Batak people to be prudent in every action (so the word 
sorry in Batak language need not to exist). It is supporting initial consciousness, one dimension of intercultural sensitivity. Kinship systems in batak as Three fire place that hula-hula, Boru, dongan Tubu.

\section{Active Sensitivity}

Everyone's Batak is king, so that our behavior should also be adjusted, such as spoken must be good, "Aek Sibara-bara tung aha pe muse na masa ndang boi mago anggo holong," meaning that no matter what love should not be lost among us related to the dimension of active sensitivity.

\section{Musyawarah mufakat and conflict avoidence}

Musyawarah mufakat:

Toba: Aek godang do, aek laut. Dos ni roha do si bahen na saut. This affluence that the bargain is going on!then, balintang ma pagebe, tumandanghon sita doan. Arinta ma pane, ai nunga masipaolo-oloan. This means that the deal happened. That is, it was mutually agreed.

To be comfortable, usually tulang (hula-hula) as those who heard and honored to be called upon to lead, coordinate the course of deliberation so that there is no conflict. If you want a party, it will be divided up their duties, who are in command for this and that (martonggor raja). Even in huta Siallagan, there are sites were there used to be a hearing to decide the punishment for those convicted. Then, if there are land disputes, it will summon the elder person to discuss the issue. The agreement is decided. Values used "marsipature Huta na be." If there was no consensus is not too prioritized comfortable atmosphere but more oriented problem solving.

(Simalungun): Sauhur sapanrinah sapangahap. Tonggo raja who there should be a dialogue the elements collected family, neighbors, to discuss the duties of each. And also there are the parsahaban pajabu consultations between the man and woman for marriage.

Sata bi hata, is the expectation that the Batak people to be prudent in every action (so the word sorry in Batak language need not to exist). It is supporting initial consciousness, one dimension of intercultural sensitivity. Kinship systems in batak as Three fire place that hula-hula, Boru, dongan Tubu.

\section{Conflict Avoidance:}

(Toba) Conflict is not to be avoided, but immediately faced. Show dominance. If there was a disagreement, resolved through love. (batu na bolon, bata na metmet. Parsoburan ni sitapi-tapi mate na bolon mate na metmet, Unang adong siombus api). Doing not play small-big fire will still be discharged. The decorum is maintained. There was Marhula Somba-hula as a control to avoid open conflict. Clever as serpents, harmless as doves (to be sincere when friends because other people and be smart in stride).

\section{Group Harmony}

Sipangan anak, sipangan boru, If you want to maintain harmony, then there should be no difference in the treatment given to each person. There are rules that direct the Mandailing community to maintain harmony, and it also must be obeyed immigrant communities living in their area.

The rule is "Poda na Lima." It contains five values that should be practiced, among others: (1) pahias rohamu (Clean your heart); (2) pahias pamatangmu (physically clean); (3) pahias pakaranganmu (clean your neighborhoods), (4) pahias bagasmu (clean the whole of your house); (5) paias parabitonmu (wash your clothes.).

According to a discussion group, there are three points that are most important to maintain harmony, namely "pahias Roha," relating to the settlement to the problem with a carefully thought out the results of consultation. "Pahias pakarangan; it relates to embodying togetherness and solidarity. "Pahias parabiton " It means with regards to manners to dress when meeting with others.

Because it was used in positions that must be respected, are interchangeable, so that the Batak people are accustomed to respect each other's position, as it allows every position, we live well. It thus does not need too much to speak, but they should respect and understand where the position is. The statement is in accordance with the dimensions musayawah mufakat and group harmony.

The result of FGD the group of Karo: indicate that the culture of the Karo also applies the importance to the values associated with the sensitivity of intercultural, among others: Value kinship and partuturan which equally important can 
be interchanged depending upon the position within the family at a given time to make the Karo mutual respect each other's position, which supports the initial dimensions of consciousness.

It means 'runggu' as the concept of deliberation, as well represented by the buildings that are used to agree and support the traditional party consensus. Efforts to maintain customs, such as mating should not semarga, Even if the marriage is done with different ethnic groups do purchase clan and communication between law rules, and laws are still quite strong that the people associated with the Karo implicit communication. 'Senina compact', meaning a fellow clan cohesiveness associated with group harmony as a dimension of intercultural sensitivity.

Simalungun group based FGD many values related to coexistence, such as the maintenance of harmony in the middle of the difference, but the issues raised with regard to the strengthening of identity to. They deemed faded. The results include: 'do not express the feeling of' this is less support implicit dimension of communication. The trend to be tolerant of others, so it tends to dissolve in othercultures, is not supporting the consensus, group harmony, conflictavoidance.

When connected to multiculturalism, as expressed by Hogg (2011), multiculturalism requires strong identity of each group with an atmosphere of tolerance and togetherness. The tendency of late on others is an indicator of their assimilation, in the case of group discussion results. Avoid conflict, in the sense, not assertive enough to defend the opinions and needs of its individual.

It does not comply with the statement Panggabean (2010) about the need for someone to understand your own culture to be able to hang out in the middle of other cultures without losing its identity. Condition's encounter with other cultures, according to Simalungun discussion groups, making them likely to adopt the culture of the other, this becomes a serious concern in the discussion in the group of participants.

The results of FGD in Mandailing group showed quite the values of the intercultural sensitivity. For example, it displayed markobar meaning of the term consensus. All families should agree on both large and small families. To deliberation or discussion with the good, the group members recognize that each meeting should bring the elder people. It is necessary to give direction and good judgment to reach an agreement that is mature. Deliberations more comfortable by sitting together, along with the meal, and as much as possible to put one's positioned on the appropriate structure in forum discussions or deliberations.

It was fairly drawn from the discussions, a sort of fear of loss of identity in the midst of life Mandailing identity as the existing variety. It attempts to refuse other cultures and become more exclusive enough displayed on the center. It was a tendency to identify with the Mandailing with religion (Islam) in an attempt to strengthen the identity of Mandailings colored with these fears. The results obtained are: The existence from the concept of 'markobar' as the concept of consensus. Even if we do not like someone or culture, we have to keep their feelings in a way being nice and polite, it supports the initial dimensions of consciousness and conflict avoidance.

It was various FGD results obtained from all seven groups as representatives of the four subethnic batak. The conclusion there are values that support the seven dimension of intercultural sensitivity, but there are also some aspects that are not as much supportive. These results certainly can be used as an ingredient for the manufacture of training to improve intercultural sensitivity based on values rooted in the local culture. It was aspects that support will be strengthened, while those aspects that are less comforting discussed during the process in order to obtain appropriate learning. It is needed making the training course. The variable flexibility of thinking and openness required attention to each step of the study.

The recommendation given should include qualitative research was conducted first in order to be used for the manufacture of measuring tools.

\section{CONCLUSION AND RECOMMENDATION}

1. Based on the results of a quantitative study found that the values of the Batak culture, flexibility of thought and openness contribute significantly to intercultural sensitivity. These results are consistent with the hypothesis that was built.

2. Based on the analysis to participants, each of the values of Batak, openness and cognitive flexibility contribute to intercultural sensitivity. 
3. It was various FGD results obtained from all seven groups as representatives of the four sub-ethnic batak. The conclusion there are values that support the seven dimension of intercultural sensitivity, but there are also some aspects that are not as much supportive.

4. These results certainly can be used as an ingredient for the manufacture of training to improve intercultural sensitivity based on values rooted in the local culture.

5. It was aspects that support will be strengthened, while those aspects that are less comforting discussed during the process in order to obtain appropriate learning. It is needed making the training course.

6. The variable flexibility of thinking and openness required attention to each step of the study.

\section{ACKNOWLEDGMENT}

Prof. Usman Pelly's thanks for viability to guid e us to knowmore about Batak, it was very helpful. $R$ atih Baiduri, thanks for your concern and our loyal st udents who help us sincerely, FauziRozi, M.Rajief, Wi caksana Adji, thank you.

\section{REFERENCES}

Anto, J. (2012). Pendidikan Multikultural untuk Kohesi Sosial. Harian Analisa, hal 2., 19 Desember

Baiduri. R (2015.)Makna Dan Dimensi Kerja Perempuan Pedagang Batak Toba (Inang-Inang) Di Kota Medan. Disertasi. Yogyakarta: S3 Jurusan Antropologi Fakultas Ilmu Budaya Universitas Gadjah Mada.

Bhwauk \& R. Brislin, D. P. S. (1992). The measurement of intercultural sensitivity using the concepts of individualism and collectivism. International Journal of Intercultural Relations, 16, 413-36.

Berger, P. \& T. Luckmann. (1966) The Social Construction of Reality: A Treatise on the Sociology of Knowledge. UK: Oxford University Press.
Cresswell. Research Design: Qualitative, Quantitative, and Mixed Methods Approaches fourth edition. 2014.

Cui \& Van Den Berg. (1991). Testing the construct validity of intercultural effectiveness. International Journal Of Intercultural Relations. 16, 311-328.

Hogg, M. A., \& G.M. Vaughan (2011). Social Psychology. 6th ed. London: Pearson.

Nauly M., \&. Fransisca, V. (2015). Identitas budaya pada mahasiswa batak toba yang kuliah di Medan. dalam Indonesian Journal of Indegenous Psychology. Vol. 2, N0. 1/Juni, hlmn 364-380. Jakarta: Konsorsium Psikologi Indonesia Nusantara.

Nauly, M. (2003) Fear of success perempuan bekerja: studi banding perempuan Batak, Minang dan Jawa. Yogyakarta: Arti.

Kayam, U. (1989). Transformasi Budaya Kita. Pidato disampaikan dalam acara pengukuhan jabatan Guru Besar pada Fakultas Sastra Universitas Gadjah Mada. Yogyakarta, 19 Mei.

Kurniawan, S. (2006). Gambaran masalah mahasiswa indonesia di Amerika dan penerapan kompetensi ICS untuk mengatasinya. Skripsi Sarjana. Jakarta: Fakultas Psikologi Unika Atmajaya.

Panggabean, H. (2010). Mengembangkan kompetensi antar budaya menjadi pluralis dengan sadar. In: 50 tahun Himpunan Psikologi Indonesia: Redefinisi Psikologi Indonesia dalam keberagaman. Hal 16-36. Supratiknya, A. \& Susana, T (eds). Jakarta: HIMPSI.

. (2004a). Characteristics of Intercultural sensitivity in Indonesian-German Work Groups. Depok: PT Fatoklesar.

(2004b) Gambaran Nilai yang Berpengaruh Pada Sensitivitas Antarbudaya Indonesia. Makalah, tidak diterbitkan. Universitas Katolik Indonesia Atma Jaya, Jakarta..

Panggabean, H \& Suryani, A. (2008) Penyusunan Alat Ukur Model Intercultural sensitivity Indonesia dan China. Dalam Wijayanti \& Sugiharto (Eds.). Prosiding Hasil Penelitian Kompetitif 2007. Jakarta: Universitas Katolik Indonesia Atma Jaya.

Partogi, S. (2011) Hubungan keterikatan dengan nilai budaya etnis dan perilaku sensitivitas 
antarbudaya pada migran batak toba di jakarta. Jakarta: Unika Atmajaya..

Pedersen, P.B. (1994) A handbook for developing multicultural awareness. Alexandria: American Counselling Association..

Rikkidaniel, A. (2006.) Hubungan antara tingkat Interkultural Sensitivity dengan tingkat keberhasilan penyesuaian diri pada mahasiswa indonesia yang belajar di Australis. Skripsi Sarjana. Jakarta: Fakultas Psikologi Unika Atmajaya.

Pelly U, (2016). Etnisitas: Dalam politik multikultural. Buku II. Medan: Casa Mesra Publisher dan Eja Publisher.
(1994).. Urbanisasi dan adaptasi: Peranan misi Budaya Minangkabau dan Mandailing. Jakarta: LP3ES.

Siahaan, N. (1982). Adat Dalihan Na Tolu: Prinsip dan Pelaksanaannya. Medan: CV Prima Anugerah.

Suparlan, P. (2001). Antropologi Indonesia dalam memasuki abad ke-21. Jurnal Antropologi Sosial dan Budaya Indonesia, 22 (58), 1-4.

Thomas, A.. (1999) Intercultural Orientation and Action. Makalah, tidak diterbitkan.. 